\title{
Influence of the Operation Conditions on the Supercapacitors Reliability Parameters
}

\author{
Ryszard Kopka, Wiesław Tarczyński \\ Opole University of Technology, Department of Electrical, Control and Computer Engineering, Sosnkowskiego 31, 45-272 Opole
}

\begin{abstract}
This paper presents the results of tests connected with measurements of capacitance and equivalent series resistance of supercapacitors, depending on value of charge/discharge current. Special circuit and algorithm for carrying out measurement procedure, to determine dependency of value of designated equivalent parameters of supercapacitor on value of current, based on which such parameters are estimated, have been prepared for this purpose. A supercapacitor of capacitance $1200 \mathrm{~F}$ has been used for the tests. Its equivalent parameters have been determined within the range of currents from $5 \mathrm{~A}$ to $20 \mathrm{~A}$. Reliability assessment has been carried out directly based on changes of values of these parameters. Complete testing procedure has been prepared in MATLAB/Simulink environment using XPC toolbox.
\end{abstract}

\section{Introduction}

Supercapacitors are electronic components that have been recently introduced into operation. Special properties distinguishing them with respect from the other types of capacitors are very high capacitance and relatively small dimensions. First major applications were voltage maintenance circuits for semi-conductor memories in the microprocessor systems. Currently they are increasingly used in power supply systems as circuit improving properties of energy sources in supply circuits using batteries or accumulators. Connection of supercapacitor in series to the battery or accumulator allows decreasing internal dynamic resistance of power supply circuit what is especially important for equipment requiring high value of current during start-up e.g. starters of combustion engines $[2,5,8]$.

High charge that can be accumulated by the supercapacitors enables low current consumption for a very long time or supplying of high value of current to the load for short period. In turn short charging time allows using supercapacitors in energy recovery and storage systems e.g. in mechanical vehicles during braking process.

Supercapacitors are characterized by high capacitance, high power density per volume and weight, very long operation period (even up to 20 years), high number of allowable charge and discharge cycles as well as almost maintenance-free ope-

Autor korespondujący:

Ryszard Kopka, r.kopka@po.opole.pl

Artykuł recenzowany

nadesłany 17.07.2015 r., przyjęty do druku 24.08.2015 r ration. Furthermore, due to use of chemical substances based on coal and organic compounds for construction they are almost inert for the environment, what allows their disposal. The other increasingly used application is use of the supercapacitors in emergency power supply circuits for on-board systems in the passenger airplanes and in uninterruptable power supply systems for computers. Such applications of the supercapacitors set the very high requirements within the scope of reliability and correctness of operation $[2,8]$.

Numerous tests and observations of the supercapacitors had indicated that during their operation there are processes causing gradual degradation of their operational features. It manifests especially by decrease of capacitance and increase of value of series internal resistance. Degradation processes are dependent on such major factors as: operation temperature, value of charge and discharge current, number of charge and discharge cycles.

To ensure correct operation of the equipment using supercapacitors as energy source it is necessary to get familiar with all factors influencing values of their parameters. Therefore, it is important that parameters of the given type of supercapacitors should be precisely measured before it is used and that they should be checked on a continuing basis during its operation [9].

Wide range of capacitance values of the supercapacitors from fractions of Farads to several thousands of Farads and value of series equivalent resistance from fractions of $m \Omega$ to several dozens of $\Omega$, and specific properties of materials used for construction of supercapacitors require use of unusual circuits and methods of carrying out of the measurements as well as calculations of values of the parameters important for the given application.

This paper describes circuit for charging and discharging of supercapacitor with relatively high capacitance and influence of such process on value of series capacitance and resistance. Such operation conditions of supercapacitor can be encoun- 
tered in uninterruptible power supply systems, where often decays of network voltage, voltage dips and so-called flicking phenomenon, are present.

Prepared test setup allows carrying out charging and discharging processes of supercapacitor based on voltage or current source with various efficiency and frequency of repetition.

\section{Supercapacitor Construction}

Supercapacitor construction is similar to construction of typical capacitor containing two electrodes and dielectric material located between them. Supercapacitor electrodes are made of aluminium strip covered with activated carbon and separated with thin insulation layer so-called separator. Activated carbon used, mainly in form of carbon nanotubes, characterizes with very high active area exceeding several thousand square meters at 1 gram of mass. Both electrodes are galvanically isolated by thin porous membrane, so-called separator, made of plastics. Separator is not a dielectric material as in case of traditional capacitors, but it only precludes electric shorting of both electrodes by the activated carbon. Electrodes and separator are additionally soaked with electrolyte (organic compound). Contact area between conducting electrodes and electrolyte are acting as a dielectric material and ions accumulated on this area are separated between each other on very small distances. Isolating layer created in this way precludes direct flow of charge to electrodes. Limit voltage value that does not cause damage of dielectric layer and separator is called decomposition voltage. Exceeding of this voltage results in breakdown and therefore shorting on border of the electrode and electrolyte what means almost irreversible damage of the capacitor. Value of this voltage depends mainly on temperature of the supercapacitor [1].

Although supercapacitors are classified as the group of electrochemical components, no chemical processes connected with this do not take place inside it. Charge in supercapacitor is accumulated only by polarization of the electrolyte, and it causes that charging and discharging is completely reversible process [10].

Equivalent circuit diagram of the supercapacitor is similar with respect to the construction to the model used for typical electrolytic capacitor (fig. 1). Model includes: capacitance $C_{A C}$, inductance $L$, series resistance $R_{S}$ and parallel resistance $R_{P}$. Capacitance $C_{A C}$ represents main capacitance of the capacitor between the electrodes, coil $L$ corresponds to the inductance resulting especially from the method of electrodes assembly (e.g. harmonious arrangement, folded arrangement) and inductance of leads, while series resistance $R_{S}$ represents resistance of leads and resistance of ionic and electron conduction of the dielectric material. Parallel resistance $R_{P}$ corresponds to leakance between the electrodes.

Values of model components depends of type of capacitor, its construction, capacitance and such factors are operating time, temperature, current value of voltage between the electrodes.

Despite similarities in construction of supercapacitor and traditional electrolytic capacitor, they have significant differences in properties. This difference applies especially to their capacities but also in definitely different behavior of supercapacitor for direct and alternating currents and voltages both with high and low frequencies [12].

Model of the supercapacitor (fig. 1) is the first order model consisting of $R L C$ components and therefore it is the same model with simple structure what causes that it does not reflect completely behavior or real capacitor during its normal operation. Primarily this model does not take into account low-frequency processes during charging and discharging as well as influence of temperature on values of capacitance. Detailed description of supercapacitors models with more developed structure can be found in $[3,6,11]$.

Considering use of supercapacitors in electronic and power electronic systems it can be assumed that to assess their properties it is enough to know properties of two primary parameters that is equivalent series resistance $E S R$ and capacitance $C_{A C}$. Series internal resistance $E S R$ is a combination of series and parallel resistance $-R_{S}$ and $R_{P}$, respectively, and it is connected with losses of energy inside the supercapacitor that are causing it internal heating.

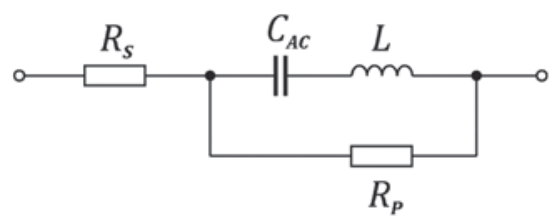

Fig. 1. Simplified equivalent circuit diagram of supercapacitor Rys. 1. Uproszczony schemat obwodu zastępczego superkondensatora

When supercapacitors are used in power supply maintenance systems or directly in electronic equipment power and power electronic supply systems, the most important parameters is $C_{A C}$ value, because it decides about maximum supply time. While in case when supercapacitors are used in power supply systems characterized with high instantaneous current consumption (e.g. starting systems of combustion engines), the series resistance ESR is a critical parameters, which value should be in such case as small as possible to minimize voltage drop during current consumption.

Variety of applications of the supercapacitors and requirements resulting from this fact with respect to the more important parameters caused that various types of supercapacitors, differing with capacity, allowable decomposition voltage, allowable range of ambient temperatures and internal resistance, have been introduced to the marked $[4,6]$.

\section{Failure Processes in Supercapacitor}

Specific properties of supercapacitors causes that they are more and more commonly used in start-up and back-up power supply systems. Very high charge, low resistance, small dimensions and weight and ease of maintenance and operation causes that these components are currently very important element of such systems. However, use of the supercapacitors as the main components of energy, imposes on them the need to maintain very high reliability. Therefore, the key issue in such systems is continuous assessment of their technical condition. Currently used diagnostic methods are based on measurements and observation of changes in time of primary equivalent parameters of the supercapacitors that is their capacitance and series equivalent resistance. These parameters can be determined both in laboratory during diagnostics tests and in real circuits systems during their daily operation. Value of these parameters is determined based on drop or increase of voltage caused by charge or discharge current. However, it appears that parameters determined in such way are strongly dependent on value of these current. It has special meaning in case of operational diagnostics in normal operation conditions. In such case, it is often that supercapacitors are charged or discharged with various values of current and there- 
fore estimated values of equivalent parameters can significantly differ from each other.

All supercapacitors, regardless of the construction and capacitance, as a result of operation are subject to degradation processes manifesting especially by decrease of capacitance $C_{A C}$ and increase of equivalent series resistance ESR. Capacitance drop is caused by decrease of active area of carbon electrodes and therefore with decrease of amount of ions accumulated in the electrolyte. Process rate depends on operation temperature of the capacitor, number of charging and discharging cycles and values of operation voltage. Adhesion processes on collector of the electrode diminishes after a time and increasing number of charging and discharging cycles causing also decrease of amount of available ions and therefore decrease of capacitance $C_{A C}$ and increase of equivalent series resistance. Practically it is assumed that capacitor, where capacitance had decreased by $20 \%$ with respect to initial value or series resistance $E S R$ increased by $100 \%$, is treated as capacitor that cannot be operated according to its initial use $[2,12]$.

\section{Test Setup and Measurement Procedure}

Supercapacitors because of their relatively very high capacitance and very small internal resistance require use the other systems and methods for measurements than in case of traditional capacitors. Precise measurements of capacitor capacitance and its changes in time are especially difficult.

Measurements of capacitors parameters should be carried out at the manufacturer's site and in some cases, especially when they are used in the power supply systems, where reliability determines the safety, also controlled during their daily operation.

Results of the capacitance measurements and internal resistance of the supercapacitor depends mainly on method of the measurements. The most important factors deciding about it are time correlations between control signals and operation temperature. Therefore, the conditions and method of carrying out of the measurements and evaluation of supercapacitors properties should be adequate to operation conditions where the given capacitor will be used.

\subsection{Measurement Procedure}

Measurements of capacitance and equivalent series resistance of the supercapacitor can be carried out using direct or alternating sinusoidal currents and voltages. In case when direct

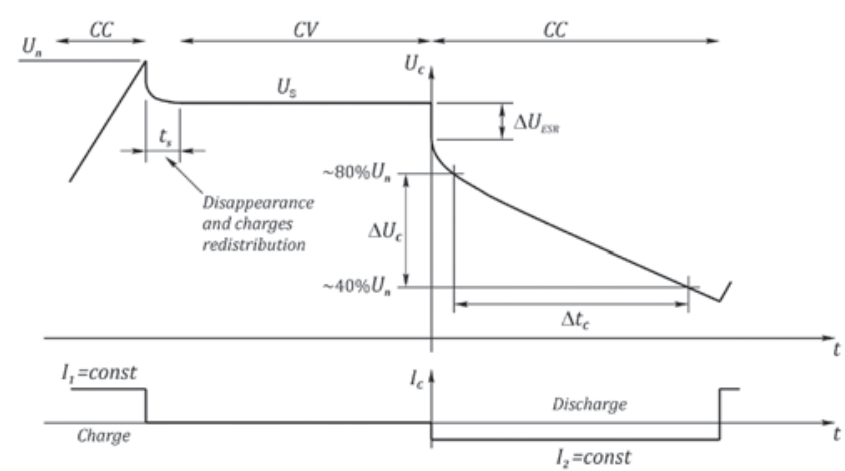

Fig. 2. Supercapacitor voltage and current curves, based on which the value of capacitance $C_{A C}$ and equivalent series resistance ESR are determined [7]

Rys. 2. Charakterystyki napięcia i natężenia prądu dla superkondensatora, na podstawie których obliczono pojemność $\mathrm{C}_{\mathrm{AC}}$ oraz zastępczą rezystancję szeregową ESR [7]

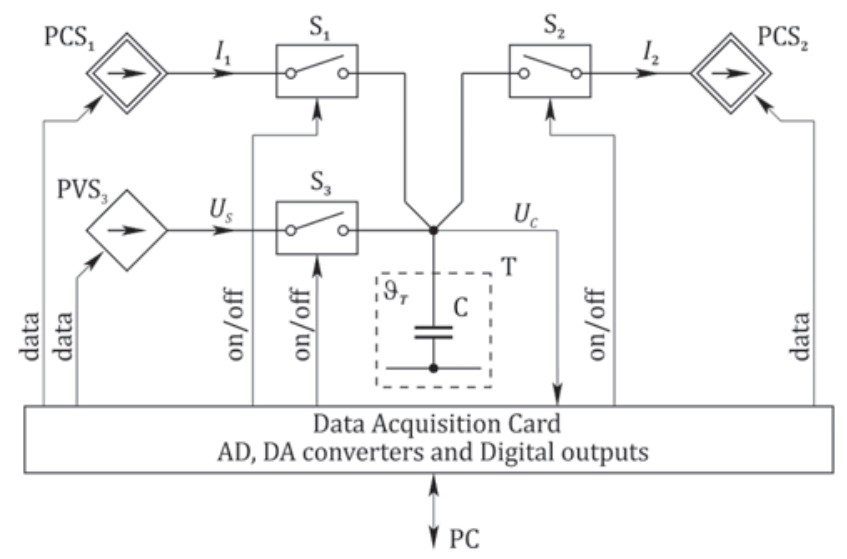

Fig. 3. Schematic diagram of measurement system for testing of the supercapacitor

Rys. 3. Schemat systemu pomiarowego do badań superkondensatora

currents and voltages are used the value of series resistance ESR and capacitance $C_{A C}$ are determined based on the charge and discharge cycle of the capacitor. Typical curve of charge and discharge time cycle is presented in the fig. 2 .

In the first stage, supercapacitor is charged from current source with constant current $I_{1}$ until rated voltage $U_{n}$ is reached (the first section of time, marked $C C$ ). When voltage $U_{n}$ is reached the supercapacitor is completely disconnected for time $t_{s}$. Sudden voltage drop occurs between ends of the capacitor during disconnection. It is caused by voltage drop on internal resistance $E S R$, while further, smooth, decrease of voltage is caused by disappearance and charges redistribution. After time $t_{s}$ voltage value on capacitor reaches value $U_{s}$. Then voltage source with voltage value equal to $U_{s}$ is connected to the capacitor, and it is maintained for third section of time, marked $C V$, that is approx. 10-30 min. All transient conditions connected with accumulation and migration of charges should be passed inside the supercapacitor during this time. After that, discharging process of supercapacitor starts by constant current from current source of efficiency $I_{2}$ (the fourth section of time, marked $C C$ again).

The value of equivalent series resistance ESR is determined based on equation

$$
E S R=\frac{\Delta U_{E S R}}{I_{2}}
$$

where $\Delta U_{E S R}$ is a supercapacitor voltage drop caused by switching on the discharge current of value $I_{2}$. While capacitance value $C_{A C}$ is determined from the formula

$$
C_{A C}=\frac{\Delta Q_{C}}{\Delta U_{C}}=I_{2} \frac{\Delta t_{C}}{\Delta U_{C}},
$$

where $\Delta U_{C}$ is a change of voltage on capacitor caused by discharge current $I_{2}$ flowing for time $\Delta t_{C}$. While $\Delta t_{C}$ is a time during which the value of voltage on capacitor changed from approx. $80 \%$ to $40 \%$ of nominal voltage value $U_{n}[7,9]$.

\subsection{Test Setup}

Diagram of test setup is presented in fig. 3. Tested capacitor C is located into temperature chamber $\mathrm{T}$ ensuring maintenance of constant ambient temperature during test. Supercapacitor $\mathrm{C}$ can be charged by current $I_{1}$ from programmable current source $\mathrm{PCS}_{1}$, and it can be discharged by current $I_{2}$ through the programmable current source $\mathrm{PCS}_{2}$. Programmable voltage source $\mathrm{PVS}_{3}$ can be connected on input of the capaci- 
a)
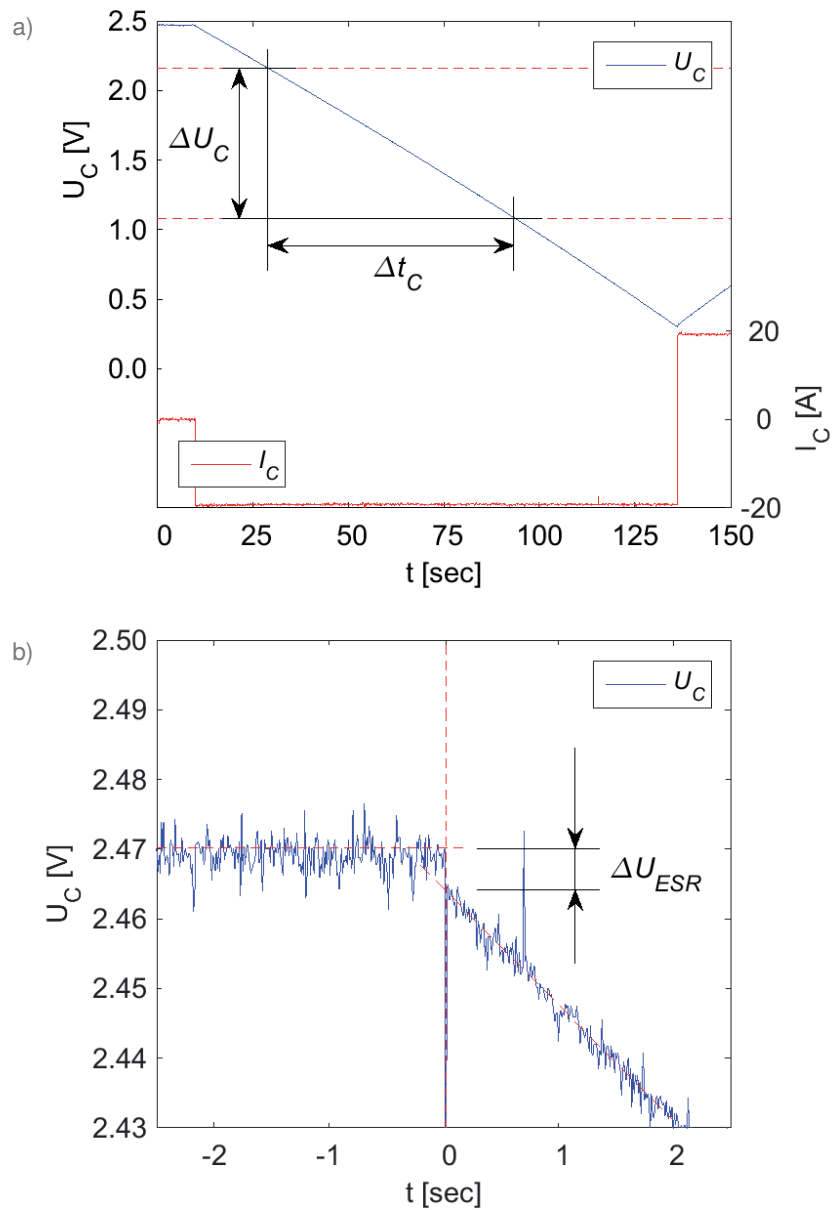

Fig. 4. Example of determination the equivalent parameters of the supercapacitor during discharging cycle for $I_{2}=20 \mathrm{~A}$, a) the capacity $\mathrm{C}, \mathrm{b})$ the equivalent series resistance ESR

Rys. 4. Przykład wyznaczania parametrów zastępczych superkondensatora podczas cyklu rozładowania dla $\mathrm{I}_{2}=20 \mathrm{~A}$, a) pojemności C, b) zastępczej rezystancji szeregowej ESR

tor $\mathrm{C}$ by the relay $\mathrm{S}_{3}$. Voltage $U_{C}$ on the capacitor is measured by use of analogue-digital converter A/D. All elements of the measuring system are controlled by control circuit, equipped with proper software including measurement procedure.

Control system based on PC with data acquisition card provides value of charge current $I_{1}$ in a digital form to output of current source $\mathrm{PCS}_{1}$. Charging process of capacitor C starts when the relay $S_{1}$ is switched on. When the relay $S_{1}$ is switched on the measurement of voltage $U_{C}$ on supercapacitor by A/D converter starts. Charging of capacitor C lasts until voltage $U_{C}$ reaches defined maximum value $U_{\max }=2.5 \mathrm{~V}$. Then current source $\mathrm{PCS}_{1}$ is disconnected by opening of relay $\mathrm{S}_{1}$. After the relay $\mathrm{S}_{1}$ is switched off the voltage on capacitor is followed for $t_{S}=2-5 \mathrm{~s}$. When this time expires, based on voltage measurement, the value of voltage $U_{S}$ on capacitor $\mathrm{C}$ is determined by the control system PC, and it is supplied in digital form to programmable voltage source $\mathrm{PVS}_{3}$. Next the relay $\mathrm{S}_{3}$ is switched on. The time of switching on the $\mathrm{S}_{3}$ relay depends on the measurements procedure and it can lasts from several seconds to approx. 30 minutes. When this time expires, the relay $\mathrm{S}_{3}$ is switched off and $\mathrm{S}_{2}$ relay is switched on connecting programmable current source $\mathrm{PCS}_{2}$ to the capacitor C. Polarization of current $I_{2}$ is opposite to the polarization of current $I_{1}$, what results in discharging of capacitor C. Results of the measurements of voltage $U_{C}$ are archived in the memory of control system PC. When the measurement is completed results from the memory of control system PC are sent to the external computer for further processing. a)

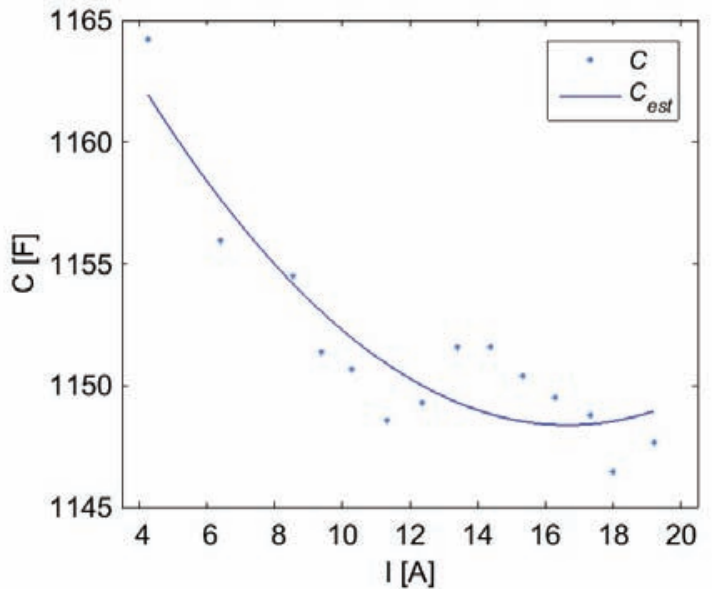

b)

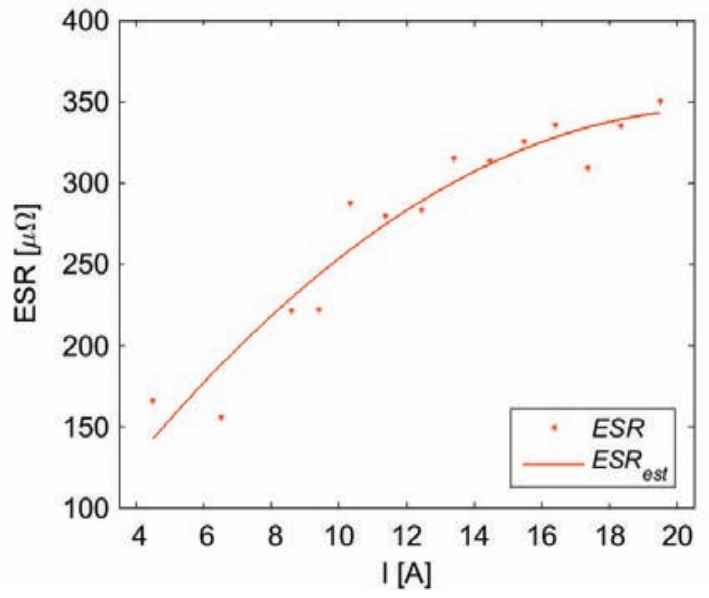

Fig. 5. Changes of values of the equivalent parameters of the supercapacitors depending on the value of discharge current, a) the capacity $C$, b) the equivalent series resistance ESR Rys. 5. Zmiany wartości parametrów zastępczych superkondensatora w zależności od wartości prądu rozładowania, a) pojemności C, b) zastępczej rezystancji szeregowej ESR

\section{Measurement Results}

For the tests the capacitor with the nominal capacitance $\mathrm{C}_{\mathrm{n}}=1200 \mathrm{~F}\left(\mathrm{U}_{\mathrm{n}}=2.7 \mathrm{~V}, \mathrm{ESR}_{\mathrm{n}}=300 \mu \Omega\right)$ has been used. Values of equivalent parameters has been determined for various currents within the range from $5 \mathrm{~A}$ to $20 \mathrm{~A}$. Because the same testing procedure should correspond to the real operational conditions, therefore time (as is during its charging and discharging) required for stabilization of conditions inside the supercapacitor was limited. This time was limited to 1 minute. Values of equivalent parameters have been determined according to the procedure presented on fig. 1, that is during capacitor discharging.

Capacitance value has been determined with measurement of voltage drop time from value $U_{1}=80 \% \cdot U_{n}=2.16 \mathrm{~V}$ to value $U_{2}=40 \% \cdot U_{n}=1.08 \mathrm{~V}$, for current within the range from 5 A to $20 \mathrm{~A}$. Voltage drop caused by equivalent series resistance $E S R$, has been determined as a distance between two straight lines, in point corresponding to time of switching on the current source discharging the capacitor. The first line has been determined as an average value from 1500 samples of voltage preceding time of current switch on. The second one, as a regression line, determined from 2500 points of voltage $U_{C}$, measured during discharging process. Measurements were carried out with $100 \mathrm{~Hz}$ sampling frequency (fig. 4).

Measurements results are presented in fig. 5. It can be seen that measurement of supercapacitor's capacitance for higher currents results in achieving of lower capacitance values $C$ and higher values of serial equivalent resistance ESR. 


\section{Conclusions}

Assessment of technical condition of the supercapacitors, especially carried out "on-line" during their operation, is very problematic. Measurement of equivalent parameters values based on various values of charge or discharge current value generates significantly different values. It can lead to making incorrect decisions corresponding to their real technical condition. Therefore, supervisory systems - operating online - should take into account conditions of the process and decisions should be made correctly taking them into consideration.

Temperature is also important factor deciding about value of equivalent parameters. During tests it was maintained on the constant level what ensured repeatability conditions for the measurement but its influence is also important. The authors currently are carrying out further measurement process works within this scope.

\section{Bibliography}

1. Chunsheng D., Ning P., High power density supercapacitor electrodes of carbon nanotube films by electrophoretic deposition, "Nanotechnology", 17/2006, 5314-5318. DOI: $10.1088 / 0957-4484 / 17 / 21 / 005$.

2. Gualous H., Gallay R., Al Sakka M., Oukaour A., Tala-Ighil B., Boudart B., Calendar and cycling ageing of activated carbon supercapacitor for automotive application, "Microelectronics Reliability", 52/2012, 2477-2481. DOI: 10.1016/j.microrel.2012.06.099.

3. Dougal R. A., Gao L., Liu S., Ultracapacitor model with automatic order selection and capacity scaling for dynamic system simulation, Journal of Power Sources, 126/2004, 250-257, DOI: 10.1016/j.jpowsour.2003.08.031.

4. Gualous H., Gallay R., Alcicek G., Tala-Ighil B., Oukaour A., Boudart B., Makany Ph., Supercapacitor ageing at constant temperature and constant voltage and thermal shock, "Microelectronics Reliability", 50/2010, 1783-1788. DOI: 10.1016/j.microrel.2010.07.144.
5. Jayalakshmi M., Balasubramanianas K., Simple Capacitors to Supercapacitors - An Overview, "Int. J. Electrochem. Sci.", 3/2008, 1196-1217.

6. Kötz R., Hahn M., Gallay R., Temperature behavior and impedance fundamentals of supercapacitors, "Journal of Power Sources", Vol. 154, No. 2/2006, 550-555. DOI: 10.1016/j.jpowsour.2005.10.048.

7. Kopka R., Tarczynski W., (2013) Measurement system for determination of supercapacitors equivalent parameters, "Metrology and Measurement Systems", Vol. 20, No. 4, 581-590. DOI: 10.2478/mms-2013-0049.

8. Mallika S., Kumar R.S., Review on Ultracapacitor- Battery Interface for Energy Management System, "International Journal of Engineering and Technology", Vol. 3, No. 1/2011, 37-43.

9. Oukaour A., Tala-Ighil B., Al Sakka M., Gualous H., Gallay R., Boudart B., Calendar ageing and health diagnosis of supercapacitor, "Electric Power Systems Research", 95/2013, 330-338. DOI: 10.1016/j.epsr.2012.09.005.

10. Pandolfo A.G., Hollenkamp A.F., Carbon properties and their role in supercapacitors, "Journal of Power Sources", Vol. 157, No. 1/2006, 11-27. DOI: 10.1016/j.jpowsour.2006.02.065.

11. Skruch P., Mitkowski W., Fractional-Orders Models of the Ultracapacitors, W. Mitkowski et al. (Eds.): Advances in the Theory and Applications of Non-Integer Order Systems, Lecture Notes in Electrical Engineering 257, Springer Switzerland, 2013, 281-293, DOI: 10.1007/978-3-319-00939-9-26.

12. Yuege Zhou, Xuerong Ye, Guofu Zhai (2011). Degradation Model and Maintenance Strategy of the Electrolytic Capacitors for Electronics Applications, [in:] Prognostics \& System Health Management Conference (PHM2011 Shenzhen), 24-25 May 2011, 1-6. DOI: 10.1109/ PHM.2011.5939474. superkondensatorów

\author{
Streszczenie: W artykule przedstawiono wyniki badań związanych z pomiarami pojemności \\ i szeregowej rezystancji zastępczej superkondensatorów w zależności od wartości natężenia \\ prądu ładowania i rozładowywania. W tym celu przygotowano specjalny układ pomiarowy \\ oraz algorytm prowadzenia badań tak, aby procedura badań była zbliżona do rzeczywistych \\ warunków eksploatacyjnych. Podczas badań wyznaczono zależność zmian wartości \\ parametrów zastępczych w funkcji wartości prądu, na podstawie których były one szacowane. \\ Do badań użyto superkondensator o pojemności 1200 F. Wartości jego parametrów \\ zastępczych wyznaczono w zakresie zmian natężenia prądu od 5 A do 20 A. Ocena \\ niezawodności została przeprowadzona bezpośrednio na podstawie zmian wartości tych \\ parametrów. Pełna procedura badania została przygotowana w środowisku MATLAB/Simulink \\ z wykorzystaniem przybornika XPC.
}




\section{Ryszard Kopka, Ph.D. Eng.}

r.kopka@po.opole.pl

He received the M.Sc. and Ph.D. degrees in electrical engineering from the Opole University of Technology in 1995 and 2004, respectively. Currently an assistant professor in the Instytut of Control and Computer Engineering. His research interest concern the possibility of using the information about degradation processes to assess the reliability of technical elements, devices or systems.

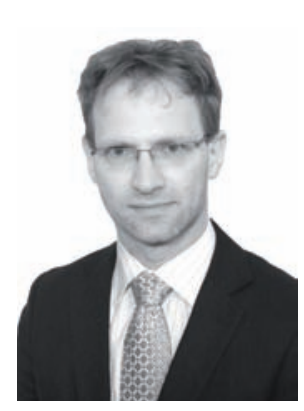

\section{Wiesław Tarczyński, Ph.D. D.Sc. Eng.}

w.tarczynski@po.opole.pl

He received the M.Sc. and Ph.D. degrees in electronic engineering from the Wrocław University of Technology in 1974 and 1983, respectively. In 2008 he received the D.Sc. degree in electric engineering from Opole University of Technology. Currently the director of the Institute of Control and Computer Engineering. His main scientific interest cover the fault detection methods, especially possibility of using the electronic equipment in diagnosis of power and tele-

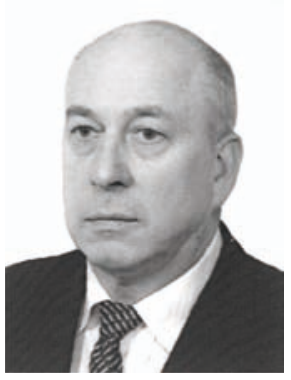
communication cables. He is the author of over a dozen patents in this field 